\title{
A Short Overview on Nutrition, Wound Healing and Medical Textiles
}

\author{
Muhammet UZUN ${ }^{1}$, Christophe BACH ${ }^{1}$, Stefan JOCKENHOEVEL ${ }^{1,2}$, Subhash ANAND ${ }^{3}$, Tahir SHAH \\ ${ }^{1}$ Institut für Textiltechnik (ITA), RWTH Aachen University, Aachen, Gemany \\ ${ }^{2}$ Department of Applied Medical Engineering, Helmholtz Institute for Biomedical Engineering, \\ RWTH Aachen University, Aachen, Germany \\ ${ }^{3}$ Institute for Materials Research and Innovation, University of Bolton, Bolton BL3 5AB, UK
}

\begin{abstract}
The objective of this paper is to determine wounds, wound healing and the effect of nutrition on wound healing. In recent times, the developments in cellular and molecular biology have greatly expanded and enhanced the current understanding of the biological processes involved in wound healing and tissue regeneration. A remarkable progress has been achieved and an ever-growing number of wound care products have been designed and developed to incorporate the latest understanding of cellular and molecular level phenomena involved in the dynamic and complex process of wound healing, including blood coagulation, inflammation, fibroplasias, collagen deposition and wound contraction. The primary goals of innovations are aimed at alleviating patient suffering; shortening wound healing time periods, and resolving chronic wound healing clinical problems. The investigation and innovation of novel wound dressing materials and methods are an important part of the fast growing biomaterials industry worldwide.
\end{abstract}

Keywords: wound healing, wound types, medical textiles, nutrition

\section{INTRODUCTION}

\subsection{Wound and Wound Types}

A wound is a type of injury in which the external tissues and blood vessels are damaged. Wound healing is a process of forming new tissues and blood vessels. Wounds are defined as "skin defects caused by mechanical, thermal, electrical and chemical injuries, or by the presence of an underlying medical or physical disorder" by Thomas in 1990 [19]. Another definition for wound healing is "the body's natural response to injury, involves a sequence of highly interdependent processes that overlap in time" [3]. The common wounds are burns, abrasions, lacerations, acute bullet or knife cuts, bites and surgical wounds. The wounds are classified into the following three categories:

a) Chronic wounds are those that involve longer healing times ranging from months to years, for example pressure sores, leg ulcers etc. The chronic wounds fail to heal even though all efforts are undertaken to aid healing and become persistent or reoccur after a period of time when the wounds have healed [10-11]. Commonly, it is accepted that if any wound does not heal within three months, it could be considered as a chronic wound. b) Acute wounds are usually traumatic wounds (cuts, abrasion, burns, etc.) and they show obvious signs of healing without any complication. They heal within reasonable time frame [12].

c) Post-operative wounds are intentional acute wounds [4].

The characterisation of wounds can be made in two different ways; a) their size, shapes, depths; and b) the location on the body. There are some parameters which must be taken into account such as the effective design of the functional wound bandage; characteristics of the wound type; the wound healing time; and the physical and chemical properties of the bandages [13-15].

\subsection{Wound Healing and its Phases}

The wound healing process consists of a series of highly complex interdependent and overlapping phases. It is the body's natural response to the wound by regenerating new layers of skin. When the wound occurs, a series of events take place immediately to repair the wounded area. In many cases, the underlying causes and factors interfering with wound healing may be multifactorial [16]. The process of healing for all wounds are similar but the duration of each

Corresponding Author: Muhammet UZUN, Tel: +90 21641405 45, E-mail: m.uzun@marmara.edu.tr Submitted: 15 October 2014, Revised: 04 March 2015, Accepted: 01 July 2015 
of the stages differs from acute to chronic wounds. A wound that heals by primary intention has minimal tissue loss; however, when there is a moderate to large amount of tissue loss, wounds heal by secondary intention with formation of granulation tissue at the proliferation stage and development of obvious scar [17]. The wound healing is characterised by a common process involving the four phases, regardless of whether the wounds are inflicted physically, chemically, or by oxidative stress. The phases of wound healing are;

- Inflammation.

- Granulation (proliferation).

- Epithelialisation.

- Remodelling (maturation).

\subsection{Nutrition and Wound Healing}

A number of studies have found that the wound healing phase is extremely energy demanding process due to the complex process of cellular and biochemical events that are dependent on the nutritional substrates available. The relationship between the wound healing and nutrition has been widely investigated. It has been found that, in addition to basic macronutrients such as protein or amino acids, carbohydrate, fat and all electrolytes, micronutrients are necessary for the wound healing stages [18]. Nutrition and wound healing are closely linked [19-23]. It has been suggested that nutrient deficiencies can have negative effects on wound healing by prolonging the inflammatory phase, decreasing fibroblast proliferation, and altering collagen synthesis [20]. The nutrient deficiencies also decrease the wound tensile strength and increase the risk of infection [24]. Adequate amounts of nutrients are needed for synthesis of nucleic acids (DNA and RNA), proteins, and other factors involved in functional tissue maturation and differentiation [25-26]. Previous studies have reported that composite nutrition support would benefit both acute and chronic wound healing. Heyman et al. [27] studied the effects of high-energy, protein-enriched supplement containing arginine, vitamin $\mathrm{C}$, vitamin $\mathrm{E}$, and zinc on chronic pressure ulcer and they found that this supplement improved overall healing of pressure ulcers.

Vitamin A is essential for epidermal proliferation and reepithelisation binding of retinol to cell surface receptors. It is also important in the inflammatory phase of chronic wound healing process, which is one of the main reasons for delayed healing. Vitamin A is also related with collagen synthesis and infection [28-30]. Vitamin B promotes cell proliferation, which helps healthy skin and muscle tone, and also enhances immune and nervous system function.

In 1971, Ehrlich et al. [31] published a paper in which they described the effect of vitamin $\mathrm{E}$ on collagen synthesis. They found that vitamin E inhibited wound healing due to the accumulation of collagen. Vitamin E, an antioxidant, maintains and stabilises cellular membrane integrity by providing protection against destruction by oxidation. Animal experiments have indicated that vitamin E supplementation is beneficial to wound healing [32-33]. Vitamin $\mathrm{K}$ is important in the hemostasis phase of wound healing [3435]. Copper and zinc are associated with increased wound elasticity and resistance [36-38]. Recent evidence suggests that the copper enhances fibroblast proliferation and topical application with copper-binding cream decrease wound healing time. Iron supplementation is also important for ulcer patients [39]. Leu et al. [40] (2012) aimed to determine the most effective topical formula for wound healing. They have investigated the effects of gold nanoparticles in wound healing with antioxidant epigallocatechin gallate and -lipoic acid.

\subsection{Tannins}

Tannins represent a unique group of phenolic metabolites in numerous woody and some herbaceous higher plant species. These secondary products exhibit a remarkably wide range of biochemical and pharmacological activities in vitro including antioxidant, antitumor, antiviral, antimicrobial, enzyme-inhibiting, and radical scavenging properties (41) Tanning is used in dyeing of basic dyes with cellulosic fibres as a mordanting process. Tannins are polyphenolic compounds having capacity of gelling under certain conditions (42).

\subsubsection{Tannin Sources}

a) Condensed tannins: Areca seed, grape, broad bean, mimosa bark, mrytan marlock, quebracho wood.

b) Hydrolysable tannins: Chesnut wood, dhawa, myrobalan fruit, oak bark, oak wood, valonia oak, sumac, tara pod, bayberry. $30-35 \%$ (in mass) of tannin in the tree bark (43).

- Various plant phenolics, including flavonoids and tannins, have been shown to have antibacterial effects (Mitscher et al., 1980; Kolodziej et al., 1999), and some of them are effective against Methicillin-resistant Staphylococcus aureus MRSA (41). 
- Tannins extracted from barbatimão species has attracted the interest of the scientific community due to their chemical activities, such as anti-inflammatory, antibacterial, antiseptic and antimicrobial, and for the treatment of leucorrhea, gonorrhea, vulvo-vaginal candidacies, gastritis, sore throat, diarrhea, bleeding, and antiulcer. The phenolic compounds contained in pistachio nuts and skins are known for their antioxidant, anti-inflammatory and antimicrobial activities (44).

\subsubsection{The Advantages of Tannin}

- Abundant

- Cheap as compare to silver

- Antioxidant, antimicrobial

- Antiseptic, inflammatory

- Most cases nontoxic

- Enough gelling properties for wound dressing application

- Hydrolysable

- In certain conditions provides acidic $\mathrm{pH}$

- Spinnability with cellulose, collagen, zein, alginate, chitosan, chitin etc.

\subsection{Classification of Medical Textiles and Application of Textile Structures}

The production and utilisation of textile materials in medical textiles started since the beginning of the civilisation. In time, the function and expectation from textile materials have expanded enormously and they have developed and formed the final versions for present-day. Nowadays, the technical textiles (smart textiles) account for a huge market due to widespread applications. Medical textiles are one of the fast-growing sectors in technical textiles [45]. The main expectations from medical textile products should be innovative and beneficial to the patients' needs. Table 1 illustrates the application of different textile structures for use in medicine. Among various medical textile products, the demand for non-implantable wound dressings is increasingly growing. Medical textiles are broadly classified as:

1- Non-implantable materials such as wound dressings, bandages, plasters, etc.

2- Extracorporeal devices such as artificial kidney liver, lung, etc.
3- Implantable materials such as sutures, vascular prostheses, artificial joints, etc.

4- Healthcare and hygiene products such as bedding, clothing, and operating room garments, wipes, etc.

Table 1. Textile structure based healthcare and medical devices [45]

\begin{tabular}{|c|c|}
\hline $\begin{array}{l}\text { Fabric } \\
\text { structure }\end{array}$ & Uses \\
\hline Nonwoven & $\begin{array}{l}\text { Surgical gowns, caps and masks, absorbent layers, } \\
\text { hygiene products, incontinence products, wound } \\
\text { dressings, scaffolds, implants, and antidecubitus } \\
\text { fleece. }\end{array}$ \\
\hline Woven & $\begin{array}{l}\text { Gauze dressings, compression bandages, plasters, } \\
\text { scaffolds, vascular prostheses, surgical gowns, } \\
\text { drapes and hospital textiles, such as sheets, blankets, } \\
\text { pillowcases, uniform and operating room textiles, } \\
\text { implants, knee supports and braces. }\end{array}$ \\
\hline Knitted & $\begin{array}{l}\text { Compression bandages, vascular prostheses, stents, } \\
\text { heart valves, ligaments and tendons, surgical ho- } \\
\text { siery, blankets, wound dressings, stockings, elasti- } \\
\text { cated net garments, pressure garments, finger band- } \\
\text { ages and spacer materials for knee braces, implants, } \\
\text { nets and hammocks. }\end{array}$ \\
\hline Crochet & $\begin{array}{l}\text { Compression bandages for compression therapy, } \\
\text { cast cloth for orthopaedic casting bandages, wound } \\
\text { dressings, bandages and implants. }\end{array}$ \\
\hline \multicolumn{2}{|c|}{ Embroidery Implants. } \\
\hline Braided & Sutures, soft tissue ligaments and implants. \\
\hline $\begin{array}{l}\text { Composite } \\
\text { materials }\end{array}$ & $\begin{array}{l}\text { Diapers, feminine hygiene, incontinence products, } \\
\text { wound dressings, scaffolds, implants and support } \\
\text { systems for treatment of pressure ulcers. }\end{array}$ \\
\hline
\end{tabular}

\section{REFERENCES}

[1] Lee, Y.H., et al. Acceleration of wound healing in diabetic rats by layered hydrogel dressing. Carbohydrate Polymers. 2012, Vol. 88, pp. 809-819.

[2] Dee, K.C, Puleo, D.A and Bizios, R. An introduction to Tissue-Biomaterial Interactions. New York : Wiley\&Sons, 2002.

[3] Zahedi, P., et al. A Review on Wound Dressings with an Emphasis on Electronicspun Nanofibrous Polymeric Bandages. Polymer Advanced Technologies. 2010, Vol. 21, pp. 77-95.

[4] Qin, Y. Advanced wound dressings. Journal of Textile Institute. 2001, Vol. 92. 
[5] Alcamo, I.E. Anatomy and physiology the easy way. New York : Barron's Educational Series Inc., 2004.

[6] Dealey, C. The care of wounds: A guide for nurses. Oxford : Blackwell Publishing Ltd, 2005.

[7] Waller, J.M. and Maibach, H.I. Age and skin structure and function, a quantitative approach (I): blood flow, $\mathrm{pH}$, thickness, and ultrasound echogenicity. Skin Research and Technology. 2005, Vol. 11, 4, pp. 221-235.

[8] http://www.americanskin.org/. [Online] [Cited: 105 2012.] http://www.americanskin.org/.

[9] Collin, P.H. Dictionary of medical terms. London : A\&B Black Publishing, 2007.

[10] Schultz, G.S., et al. Wound bed preparation: a systematic approach to wound management. Wound Repair and Regeneration. 2003, Vol. 11, pp. 1-28.

[11] Gottrup, F. Oxygen in wound healing and infection. World Journal of Surgery. 2004, Vol. 28, 3, pp. 312315 .

[12] Enoch, S. and Price, P. Cellular, molecular and biochemical differences in the pathophysiology of healing between acute wounds, chronic wounds and wounds in the elderly. Worldwidewounds.com.

[13] Thomas, S. A Guide to Dressing Selections. Journal of Wound Care. 1997, Vol. 6, pp. 327-330.

[14] Enoch, S. and Leaper, D.J. Basic Science of Wound Healing. Surgery. 2005, Vol. 23, 2.

[15] Board, Northern Health and Social Services. http:// www.nhssb.n i.nhs.uk/publications/primary_care/ Wound_Manual.pdf. http://www.nhssb.n-i.nhs.uk/. [Online] [Cited: 1202 2012.]

[16] Schumann, D. The nature of wound healing. AORN Journal. 1982, Vol. 35, 6, pp. 1068-1077.

[17] Gabriel, A., et al. http://www.podiatrym.com/cme/ CME811.pdf. [Online] [Cited: 126 2012.]

[18] Stechmiller, J.K., Cowan, L. and Logan, K. Nutrition support for wound healing. Support Line. 2009, Vol. 31, pp. 2-8.

[19] Arnold, M. and Barbul, A. Nutrition and wound healing. Plast Reconstr Surg. 2006, Vol. 117, pp. 42-58.

[20] Stechmiller, J.K., Cowan, L. and Logan, K. Nutrition support for wound healing. Support Line. 2009, Vol. 31, pp. 2-8.
[21] Stratton, T.J., et al. Enteral nutritional support in prevention and treatment of pressure ulcers: a systematic review and meta-analysis. Age Res Rev. 2005, Vol. 4, pp. 422-450.

[22] Langemo, D., et al. Nutritional considerations in wound care. Adv Skin Wound Care. 2006, Vol. 19, pp. 297-303.

[23] Posthauer, M.E. The role of nutrition in wound care. Adv Skin Wound Care. 2006, Vol. 19, pp. 43-52.

[24] Campos, A.C.L., Groth, A.K. and Branco, A. Assessment and nutritional aspects of wound healing. Curr Opin Clin Nutr Metab Care. 2008, Vol. 11, pp. 281-288.

[25] Lansdown, A.B.G. Nutrition 2: a vital consideration in the management of wounds. Br J Nurs. 2004, Vol. 13, 1, pp. 1199-1210.

[26] Hunt, T.K. and Hussain, Z. The wound environment. [book auth.] I.K. Cohen, R.F. Diegelmann and W.J. Lindblad. Wound healing: biochemical and clinical aspects. Philadelphia : Saunders, 1992.

[27] Heyman, H., et al. Benefits of an oral nutritional supplement on pressure ulcer healing in long-term care residents. J Wound Care. 2008, Vol. 17, pp. 476-480.

[28] Rojas, A.I. and Phillips, T.J. Patients with chronic leg ulcers show diminished levels of vitamins $\mathrm{A}$ and $\mathrm{E}$, carotenes, and zinc. Dermatol Surg. 1999, Vol. 25, pp. 601-604.

[29] Petry, J.J. Surgically significant nutritional supplements. Plast Reconst Surg. 1996, Vol. 97, pp. 233-240.

[30] Bailley C, Dreze S, Asselineau D, et al. Retinoic acid inhibits the production of collagenase by human epidermal keratinocytes. J Invest Dermatol. 1990, Vol. 94, pp. 47-51.

[31] Ehrlich, H.P., Tarver, H. and T.K., Hunt. Inhibitory Effects of Vitamin E on Collagen Synthesis and Wound Repair. Ann. Surg. 1972, Vol. 175, 2, pp. 235-240.

[32] Arnold, M. and Barbul, A. Nutrition and wound healing. Plast Reconstr Surg. 2006, Vol. 117, 7, pp. 42-58.

[33] Burgess, C. Topical vitamins. J Drugs Dermatol. 2008, Vol. 7, 7, pp. 2-6.

[34] Goskowicz, M. and Eichenfield, L.F. Cutaneous findings of nutritional deficiencies in children. Curr Opin Pediatr. 1993, Vol. 5, pp. 441-445. 
[35] Jenkins, M.E., et al. A prospective analysis of serum vitamin $\mathrm{K}$ in severely burned pediatric patients. J Burn Care Rehabil. 1998, Vol. 2, pp. 780-782.

[36] Agren, M.S., et al. Selenium, zinc, iron and copper levels in serum of patients with arterial and venous leg ulcers. Acta Derm Venereol. 1986, Vol. 66, pp. 237240.

[37] Gosling, P., et al. Serum copper and zinc concentrations in burns in relation to surface area. J Burn Care Rehabil. 1995, Vol. 16, pp. 481-486.

[38] Vaxman, F., et al. Effect of pantothenic acid and ascorbic acid supplementation on human skin wound healing process. Eur Surg Res. 1995, Vol. 27, pp. 158166.

[39] Ringsdorf, W.M. and Cheraskin, E. Vitamin C and wound healing. Oral Surg Oral Med Oral Pathol. 1982, Vol. 53, pp. 231-236.

[40] Leu, J.G., et al. The effects of gold nanoparticles in wound healing with antioxidant epigallocatechin gallate and -lipoic acid. Nanomedicine: Nanotechnology, Biology, and Medicine. 2012, Vol. 8, pp. 767-775.

[41] Kolodziej, H., Kiderlen A.F., Antileishmanial activity and immune modulatory effects of tannins and related compounds on Leishmania parasitised RAW 264.7 cells. Phytochemistry 66 (2005) 2056-2071.

[42] Samanta, A.K., Konar, A. Dyeing of Textiles with Natural Dyes. http://cdn.intechopen.com/pdfswm/23051.pdf

[43] Mokhtarpour, A., Naserian, A.A., Valizadeh, R. Extraction of Phenolic Compounds and Tannins from Pistachio By-products. Annual Research \& Review in Biology 4(8): 1330-1338, 2014.

[44] Pawar, R.S., Toppo, F.A. Plants that heal wounds. A review, Herba Polonica, Vol. 58 No. 12012.

[45] Anand, S.C., Kennedy, J.F., Miraftab M., Rajendran, S. Medical textiles and biomaterials for healthcare. Cambridge : Woodhead, 2006 